prof. dr hab. Andrzej Prusek ${ }^{1}$

Uniwersytet Ekonomiczny w Krakowie

Polskie Towarzystwo Ekonomiczne Oddział w Krakowie

\title{
Nowa pokryzysowa polityka rozwoju zrównoważonego a polska Strategia Odpowiedzialnego Rozwoju
}

\section{WSTĘP}

Światowy i europejski kryzys finansowo-ekonomiczny dokonał zasadniczych przewartościowań w ocenie rynkowych modeli rozwoju i wynikających z nich politykach rozwoju społeczno-ekonomicznego. Syntetyczny wniosek jest jednoznaczny i wskazuje na to, że neoliberalny model gospodarczy i polityka ekonomiczna na nim bazująca doprowadziły do kryzysu, a w konsekwencji również do destabilizacji finansów publicznych państw, ogromnego bezrobocia i polaryzacji dochodowej społeczeństw (Kołodko, 2010a; Kowalik, 2010; Żyżyński, 2010; Prusek, 2011). Główną hipotezą badawczą jest stwierdzenie, że tylko nowa polityka rozwoju bazująca na pokryzysowych doświadczeniach i nowych teoriach rozwoju mogą zapewnić Polsce szanse na przełamanie pułapki średniego rozwoju.

Celem artykułu jest pokazanie relacji i współzależności między nowymi pokryzysowymi teoriami i politykami rozwoju zrównoważonego integrującego rozwój gospodarczy, społeczny, ekologiczny i przestrzenno-regionalny a wdrażaną obecnie w Polsce Strategią Odpowiedzialnego Rozwoju, będącą zarazem instrumentem przełamywania bariery w postaci pułapki średniego poziomu rozwoju.

G.W. Kołodko trafnie określił istotę neoliberalizmu: „Lansowany przez neoliberalizm system gospodarczy podporządkowany jest interesom zamożniejszych warstw $i$ to do nich trafia coraz większa część dochodu narodowego, nieekwiwalentna z punktu widzenia ich własnego wkładu. W długofalowej strategii społecznie zrównoważonego rozwoju potrzebna jest natomiast harmonia pomiędzy obowiązkami i beneficjami pracodawców i pracobiorców, czyli, nazywając rzecz po imieniu, pomiędzy kapitałem (w dużym stopniu zagranicznym) i pracą (prawie całkowicie krajową). Neoliberalizm taką harmonię wyklucza, co musi skutkować perturbacjami nie tylko gospodarczymi, lecz także społecznymi i politycznymi.

\footnotetext{
${ }^{1}$ Adres korespondencyjny: e-mail: and.prusek@gmail.com.
} 
Będą się one nasilać. Co gorsza, istota kryzysu jest taka, że obarcza on swymi ciężarami przede wszystkim nie tych, których idee i polityka - oraz krótkowzroczność i zachłanność - doń doprowadziły" (Kołodko, 2010b, s. 96).

Fundamentalną przyczyną narastania barier, a jednocześnie wyzwań rozwojowych Polski był i jest narzucony nam przez Zachód neoliberalny model transformacji społeczno-ekonomicznej, korzystny dla Zachodu, a dla Polski bardzo bolesny i generujący duże problemy. Ten model, bazujący na założeniach konsensusu waszyngtońskiego, doprowadził do ukształtowania się obecnych barier rozwojowych Polski, które w okresie pokryzysowym musimy przełamać, aby wyjść z pułapki średniego rozwoju.

Samodzielne działanie mechanizmów rynkowych nie rozwiązuje problemów przyszłości i nie jest w stanie sprostać wyzwaniom rozwojowych ludzkości, w tym zwłaszcza polaryzacji dochodowej społeczeństw, co jednoznacznie wykazał T. Piketty (2015; Prusek, 2017). Nasilające się napięcia mogą wg J. Sachsa (2007) doprowadzić do konfliktu cywilizacji, co może się okazać naszym ostatnim i całkowicie wyniszczającym starciem.

Społeczna nauka Kościoła w encyklice Jana Pawła II Sollicitudo rei socialis słusznie piętnuje mechanizmy ekonomiczne, finansowe i społeczne, które „umacniają stan bogactwa jednych i ubóstwa drugich". Mechanizmy te stworzone przez kraje rozwinięte ,sprzyjają interesom tych, którzy nimi manewrują, a doprowadzają do zdławienia i uzależnienia gospodarki krajów słabiej rozwiniętych" (Encyklika..., 1987). W encyklice Caritas in veritate (Miłość w prawdzie) papież Benedykt XVI trafnie stwierdza, że o rozwiązywanie problemów społecznych, czyli osiąganie dobra wspólnego powinna się troszczyć przede wszystkim wspólnota polityczna. Dlatego przyczyną poważnego braku równowagi jest oddzielenie działalności ekonomicznej, do której należałoby wytwarzanie bogactw, od działalności politycznej, do której należałoby osiąganie sprawiedliwości przez redystrybucję dóbr. Tego typu ideologią, która przyniosła olbrzymie koszty społeczne, w skali światowej, jest neoliberalizm, jako skrajna apologetyka zysku za wszelką cenę, bez liczenia się z wymogami etycznymi i człowiekiem (Encyklika..., 2009).

Neoliberalny plan transformacji stał w zasadniczej sprzeczności z Konstytucją RP, która w art. 20 stanowi, że: „Społeczna gospodarka rynkowa oparta na wolności działalności gospodarczej, własności prywatnej oraz solidarności, dialogu i współpracy partnerów społecznych stanowi podstawę ustroju gospodarczego". Podobna sprzeczność dotyczy art. 2 Konstytucji, który głosi, że: „Rzeczpospolita Polska jest demokratycznym państwem prawnym, urzeczywistniającym zasady sprawiedliwości społecznej”. Ten artykuł stoi w rażącej sprzeczności z dużą polaryzacją dochodowo-majątkową polskiego społeczeństwa oraz wieloletnim wysokim bezrobociem i dużą migracją zarobkową młodego, wykształconego pokolenia Polaków. Trudno też uznać, że model ten kieruje się zasadą zrównoważonego rozwoju, o której mówi art. 5 polskiej Konstytucji. 
Niezbędne jest zatem stworzenie nowego modelu funkcjonowania gospodarki i społeczeństwa, który jako alternatywny do skompromitowanego modelu neoliberalnego winien być oparty na koncepcji społecznej gospodarki rynkowej, ze znaczącym udziałem państwa w gospodarce i życiu społecznym (Prusek, 2015). Powinien on uwzględniać również nowe pokryzysowe poglądy i doświadczenia praktyczne. Winien on być z jednej strony modelem polityki zrównoważonego rozwoju uwzględniającym wyniki badań T. Pikettego w zakresie negatywnego oddziaływania polaryzacji dochodowej na rozwój gospodarczy przez spadek popytu społecznego i kreowanie „gospodarki nadmiaru”, co stwarza presję kryzysową, a następnie kryzys. Po drugie, winien to być model polityki rozwoju uwzględniający założenia i doświadczenia Justina Yifu Lina - byłego głównego ekonomisty Banku Światowego i lidera chińskiego modelu polityki rozwoju, który doprowadził Chiny do pozycji wiodącego ekonomicznego mocarstwa światowego. Jego Nowa Ekonomia Strukturalna wykazała, że państwa rozwijające się, próbujące doganiać kraje najwyżej rozwinięte, w warunkach polityki rozwoju bazującej na zalecanym przez Bank Światowy konsensusie waszyngtońskim nie mają żadnych szans i muszą trwać w pułapce średniego dochodu.

Polska znajdowała się w pułapce średniego rozwoju, którą przełamuje obecnie przez przyjęcie nowego modelu rozwoju bazującego na endogenicznych determinantach rozwoju, wzmocnieniu funkcji państwa w rozwoju gospodarczym, uszczelnianiu budżetu państwa oraz realizowaniu prospołecznej polityki rozwoju, która z jednej strony zmniejsza polaryzację dochodową społeczeństwa, a z drugiej strony dynamizuje rozwój gospodarczy przez rosnący popyt biedniejszych warstw społeczeństwa oraz dynamizuje przyrost naturalny ludności, co stwarza szanse w przyszłości.

Tak więc, w okresie pokryzysowym w Polsce realizowane jest nowatorskie myślenie i działanie w kategoriach strategicznych wyrażające się opracowaniem strategii rozwoju kraju stwarzającej szanse na zrównoważony rozwój w przyszłości oraz prowadzenie racjonalnej i niekonwencjonalnej polityki rozwoju gospodarczego, społecznego, ekologicznego i przestrzennego uwzględniającej niestandardowe rozwiązania pokryzysowe.

\section{Neoliberalny model rozWoju w Polsce}

\section{JEGO KONSEKWENCJE}

Kryzys światowy ukazał także pełną paletę wad neoliberalnego modelu funkcjonującego w polskiej gospodarce i polityce społeczno-ekonomicznej tworząc ogromne bariery jej rozwoju. Głównym megawyzwaniem, a zarazem megabarierą rozwojową Polski jest zespół wzajemnie sprzężonych barier rozwojowych związanych z demografią, rynkiem pracy i polityką dochodową, a mianowicie (Prusek, 2012a, s. 51-63; Prusek, 2012b): 
- bariera demograficzna związana ze spadkiem ludności Polski, ujemnym przyrostem naturalnym, starzeniem się społeczeństwa, niskim poziomem aktywności zawodowej, dużą migracją zarobkową młodych wykształconych obywateli za granicę, do krajów UE-15,

- bariera dochodowa wynikająca z rażąco niskiego poziomu płac w stosunku do analogicznych pod względem charakteru i wydajności miejsc pracy w krajach UE-15. Ta bariera dotyka w szczególności młode pokolenie Polaków, którzy nie mając pracy nie mogą sobie kupić mieszkania i założyć rodziny, co w konsekwencji powoduje ujemny przyrost naturalny, a także konieczność emigracji zarobkowej. Jest ona powiązana $\mathrm{z}$ barierą dużej polaryzacji dochodów, która stoi w sprzeczności z ideą sprawiedliwości społecznej oraz osłabia dynamikę rozwoju gospodarczego

Bariera demograficzna mogłaby spowodować zmniejszenie liczby ludności Polski do 2030 roku do poziomu $35 \mathrm{mln}$ osób, a do 2050 roku do 25-30 mln osób. Oznaczałoby to spadek potencjalnego PKB i dochodów sektora publicznego oraz stopniowy upadek systemu emerytalnego. W przypadku zwiększenia się dynamiki emigracji zarobkowej, która miałaby w coraz większym stopniu charakter emigracji trwałej, regres demograficzny w Polsce mógłby być jeszcze większy.

Bariery te były naturalną konsekwencją procesów deindustrializacji i prywatyzacji polskiej gospodarki, a także nieracjonalnej polityki płacowo-dochodowej (Prusek, 2005). Podzielam pogląd A. Karpińskiego, że deindustrializacja w Polsce była, przedwczesna, ekonomicznie nieuzasadniona i szkodliwa dla dynamiki gospodarczej, a zwłaszcza rynku pracy. Deindustrializację należy uznać za największy błąd strategiczny polskiej transformacji (Karpiński, 2002, s. 79). Drugim poważnym błędem było zaniechanie restrukturyzacji państwowych przedsiębiorstw mających szanse na uzyskanie konkurencyjności międzynarodowej i ich nieekwiwalentna wyprzedaż kapitałowi zagranicznemu.

Bariera dochodowa w Polsce została spowodowana urzędowym, czyli administracyjnym podniesieniem cen na środki produkcji w ramach tzw. reformy cen zaopatrzeniowych w 1990 roku i jednoczesnym skrajnie niesymetrycznie niskim wzrostem płac i zablokowaniem ich wzrostu, najpierw przez tzw. popiwek, czyli niezgodny logiką rynkową podatek od wzrostu tzw. ponadnormatywnych wynagrodzeń, a następnie przez nadrestrykcyjną politykę antyinflacyjną (Prusek, 2009). Zwalczała ona zatem nie normalną inflację, lecz urzędową, czyli dostosowawczą, czyli zarazem wzrost płac i dostosowanie ich do poziomu cen i płac europejskich. Tym samym utrzymywała ona globalną nierównowagę między popytem i podażą, hamowała rozwój gospodarczy i tworzenie nowych miejsc pracy, generowała bezrobocie, a zatem była pozbawiona racjonalności ekonomicznej i społecznej.

Uważam, że stopniowy, ale możliwie szybki wzrost płac w Polsce dostosowujący je do poziomu płac w krajach UE-15 może stać się motorem rozwoju gospodarczego i społeczno-demograficznego. Wydatki budżetowe na wzrost 
płac w sferze usług społecznych i politykę społeczną traktować należy jako wydatki inwestycyjno-rozwojowe, którą przyniosą wzrost jakości świadczonych usług oraz wzrost gospodarczy wywołany nakręceniem koniunktury przez impuls popytowy.

Doświadczenia światowe i skandynawskie jednoznacznie wskazują, że nie można tworzyć gospodarki opartej na wiedzy przy niskich płacach, gdyż uniemożliwi to drenaż mózgów i wyjazdy wykształconych ludzi do krajów oferujących im wyższe dochody oraz lepsze warunki wykonywania prac naukowo-badawczych i wdrożeniowych. Tak więc, najkorzystniejszym kierunkiem inwestowania jest wzrost nakładów na rozwój kapitału ludzkiego oraz sektora naukowo-badawczego, które tworzą trwałe i długofalowe podstawy innowacyjności i konkurencyjności gospodarek (Tomczak, 2017).

Można postawić hipotezę, że w dotychczasowej polityce podatkowej w Polsce największe ciężary ponoszą ludzie o średnim i niskim statusie dochodowym, głównie przez podatki pośrednie. Natomiast przedsiębiorstwa, w tym zwłaszcza zagraniczne, są mniejszościowym płatnikiem podatków dochodowych lub są $\mathrm{z}$ nich całkowicie zwolnione, gdyż funkcjonują w SSE.

Niezbędne są też w Polsce proinnowacyjne przekształcenia strukturalne w sektorze przedsiębiorstw i budowanie GOW, aby polskie firmy awansowały w światowym łańcuchu wartości dodanej. Niezbędna jest kontynuacja polityki wzrostu płacy minimalnej w polskiej gospodarce. Płaca minimalna winna być minimalnym kryterium efektywności gospodarowania przedsiębiorstw, która jednocześnie wymusza podnoszenie ich konkurencyjności i innowacyjności, a tym samym stwarza warunki do wzrostu płac i zmniejszania nierówności społeczno-ekonomicznych.

$\mathrm{Na}$ świecie przemysł jest nadal największym twórcą innowacji i ich wchłaniania oraz komercjalizacji, czyli przekształcania w nowe poszukiwane towary. Polska była dotychczas głównie biorcą innowacji w przemyśle, czyli imitatorem, gdyż kupowaliśmy innowacyjne rozwiązania zamiast sami je generować. Innowacje są warunkiem naszego rozwoju, gdyż generują większą wartość dodaną w firmach, a w konsekwencji tworzą warunki do budowania polskiego kapitału rozwojowego oraz wyższych płac.

W lutym 2016 roku Komisja Europejska upomniała Polskę za rażące naruszenie praw społecznych, z uwagi na 30\% udziału umów ,śmieciowych" na rynku pracy. Komisja uznała to za rekordową segmentację rynku pracy w skali UE. W Polsce jest konieczne zrównanie umów cywilnoprawnych z umowami o pracę, czyli ich oskładkowanie i opodatkowanie wszystkich rodzaje umów o pracę, aby tym samym zmniejszyć wyzysk pracowników, zwiększyć ich przyszłe emerytury oraz ograniczyć migracje zarobkowe.

W Polsce mieliśmy do czynienia ze skrajnym modelem neoliberalnym w Europie, czego dowodem był fakt, że znaczny wzrost wydajności pracy w okresie transformacji nie został ekwiwalentnie uwzględniony we wzroście płac, co oznaczało kapitalistyczny wyzysk ludzi pracy, w tym zwłaszcza młodego salatariatu 
i prekariatu (Kołodko, 2010, s. 94). Modelowym rozwiązaniem dla Polski w zakresie rynku pracy są doświadczenia szwedzkie i ich aktywna polityka zatrudnienia łącząca radykalizm gospodarczy z solidaryzmem społecznym (Kowalik, 2010b, s. 26).

Znaleźliśmy się w pułapce średniego rozwoju, gdyż nie nastąpiła w Polsce endogeniczna, proinnowacyjna restrukturyzacja gospodarki i nie zbudowano GOW. Natomiast dynamiczne procesy nieekwiwalentnej prywatyzacji polskich przedsiębiorstw oraz szeroki napływ BIZ, korzystających szeroko z preferencji podatkowych w SSE oraz taniej siły roboczej, spowodowały zdominowanie polskiej gospodarki przez kapitał zagraniczny. Polska stała się w ten sposób gospodarką zależną, typu neokolonialnego, z której więcej kapitału corocznie wypływa niż przypływa pomocy unijnej (Plan..., 2016).

Wyzwaniem rozwojowym Polski jest konieczność zasadniczego wzmocnienia dochodów sektora publicznego, aby był on w stanie realizować konstytucyjnie określone funkcje społeczne, gospodarcze, obronne i ekologiczne. Jedyne racjonalne rozwiązanie musi polegać na wprowadzeniu wyższego i progresywnego opodatkowania firm, zwłaszcza sektora finansowego, i bogatszych warstw społeczeństwa, zwiększenie ściągalności podatków oraz repolonizacja sektora finansowego.

Konieczna jest zatem sanacja polskiej narodowej gospodarki, jej proinnowacyjna restrukturyzacja i zwiększenie udziału sektora publicznego $\mathrm{w}$ dochodach płynących z jej funkcjonowania. Niezbędne jest również podniesienie sprawności funkcjonowania państwa.

Uważam, że jedyną szansą rozwojową Polski w pokryzysowych warunkach konieczne jest opracowanie i wdrożenie sterowanej przez państwo strategii rozwoju. Ta strategia zmiany sterowanej winna mieć na celu stworzenie innowacyjnych narodowych specjalizacji gospodarczych konkurencyjnych na rynkach światowych. Jest to możliwe tylko przy aktywnym udziale prywatnego sektora przedsiębiorstw, który winien preferować endogeniczne i proinnowacyjne przekształcenia strukturalne swoich przedsiębiorstw, przy wsparciu publicznym, tj. unijnym i krajowym.

Dlatego szansę rozwoju dać może Polsce tylko scenariusz sterowanych przez państwo endogenicznych i proinnowacyjnych przekształceń strukturalnych wspartych przez kapitał krajowy i zagraniczny. Scenariusz zmiany sterowanej zakłada wzmocnienie pozycji państwa, tak aby mogło ono realizować swoje konstytucyjnie określone funkcje społeczne i gospodarcze, aby mogło prowadzić politykę rozwoju, głównie w oparciu o własne, endogeniczne środki finansowe, a nie tylko lub głównie Unii Europejskiej.

Celem strategii rozwoju państw jest dostosowane do tych wyzwań, gdyż tylko wtedy możliwy jest ich długofalowy rozwój gospodarczy i społeczny. Zdolność i umiejętność dostosowywania się krajów do globalnych wyzwań rozwojowych uzależniona jest od wielu uwarunkowań. Do nich zaliczyć należy przede wszystkim: model realizowanej polityki społeczno-ekonomicznej, programowanie roz- 
woju, wspieranie rozwoju demograficznego i kapitału ludzkiego oraz proinnowacyjnych przekształceń strukturalnych w gospodarce.

Współistnienie mechanizmów rynkowych i świadomego oddziaływania państwa na funkcjonowanie gospodarki i życia społecznego jest po kryzysie standardem nowoczesnego państwa oraz jego polityki rozwoju. Uważam, że na drodze poszukiwania wyższej racjonalności i efektywności modeli funkcjonowania państwa musimy bazować na racjonalnym pragmatyzmie, a odrzucić dogmatyzm rynkowy. Dla przezwyciężenia współczesnego kryzysu konieczne jest nakierowanie nowej polityki rozwoju na myślenie w kategoriach ładu i racjonalności społecznej i ekonomicznej, na której opiera się koncepcja ordoliberalna i społecznej, inkluzyjnej gospodarki rynkowej. Realizacja tej koncepcji rozwoju wymaga nowego ładu społeczno-ekonomicznego oraz zasadniczego wzmocnienia siły państwa i jego instytucji, które winny być fundamentem nowych instytucjonalnych warunków gospodarowania i posiadać przewagę nad rynkami finansowymi (Mączyńska, Pysz, 2014). Polsce potrzebny jest nowy program rozwoju, który w polskim interesie narodowym musi umiejętnie wykorzystać megatrendy współczesności. Program ten zapewni wyższą dynamikę rozwoju gospodarczego i społecznego przez zmniejszenie skali nierówności oraz rozwój kapitału ludzkie-

go. Źródłem finansowania tych przekształceń winny być nowe źródła dochodów budżetowych, jak uszczelnienie budżetu w zakresie VAT, progresywne podatki dochodowe i likwidacja nadmiaru ulg.

Założenia te w dużym stopniu spełnia „Strategia Odpowiedzialnego Rozwoju" M. Morawieckiego. Jestem przekonany, że ten kierunek strategicznego działania jest fundamentalnym priorytetem w tej Strategii. Jego koncepcja zakłada realizację priorytetów wynikających z pięciu filarów rozwoju gospodarczego, a mianowicie: reindustrializacji, rozwoju innowacyjnych firm, tworzenia kapitału dla rozwoju, ekspansji zagranicznej oraz rozwoju społecznego i regionalnego.

Należy także popierać ekspansję nielicznych polskich championów gospodarczych wchodzących na rynki światowe i europejskie. Jednocześnie należy wyeliminować niezgodną w unijną polityką konkurencyjności praktykę dyskryminacji polskich firm na rynkach UE przez dominujące na nich firmy, przy milczącej akceptacji przez Komisję Europejską. O tym dobitnie świadczy niezgodna $\mathrm{z}$ unijnym prawem konkurencji dyskryminacja polskiej firmy Fakro przez duńską firmę Velux na rynku okien dachowych (Dlaczego...).

\section{Zalecenia Nowej Ekonomit Strukturalnej J.Y. Lina} DLA KRAJÓW ZNAJDUJĄCYCH SIĘ W PUŁAPCE ŚREDNIEGO DOCHODU

J.Y. Lin trafnie stwierdza, że teorie ekonomiczne powinny pomagać nam zrozumieć ukryte determinanty zjawisk ekonomicznych. Teorie ekonomiczne winny pomagać ludziom nie tylko zrozumieć świat, ale również go zmieniać w pożąda- 
nym kierunku. Lecz jeśli decyzje ekonomiczne podejmowane na ich podstawie nie prowadzą do pożądanych i zamierzonych celów, oznacza że są błędne i musimy je rewidować lub tworzyć nowe. Takiej zasadniczej rewizji wymaga zalecany krajom doganiającym przez Bank Światowy tzw. konsensus waszyngtoński i cały neoliberalizm.

Jego Nowa Ekonomia Strukturalna wykazała, że państwa rozwijające się, próbujące doganiać kraje najwyżej rozwinięte, w warunkach polityki rozwoju bazującej na zalecanym przez Bank Światowy konsensusie waszyngtońskim nie mają żadnych szans i nie mogą się wyrwać z pułapki średniego dochodu (Lin, 2017). J.Y. Lin słusznie stwierdza, że rozwój gospodarczy jest procesem nieustannych przemian strukturalnych, głównie w przemyśle, które podnoszą wydajność pracy oraz rozwój infrastruktury i instytucji, co z kolei wpływa na obniżenie kosztów transakcyjnych. Dlatego polityka przemysłowo-innowacyjna stanowi właściwe narzędzie do prowadzenia nowej polityki rozwoju. NES uważa, że czynnikiem o znaczeniu decydującym dla sukcesu rozwojowego jest państwo, gdyż tylko ono jest w stanie prowadzić długofalową politykę przemysłowo-innowacyjną. Polityka ta winna ułatwiać przedsiębiorstwom, prywatnym i publicznym, wchodzenie do branż cechującą się ukrytą przewagą komparatywną przez pokonanie uzewnętrznienia wartości przez pierwszego inicjatora, lidera oraz koordynowanie wymaganych udoskonaleń w twardej i miękkiej infrastrukturze. Te branże posiadające ukrytą przewagę komparatywną winny stać się narodowymi czempionami gospodarczymi.

Polityka przemysłowa w krajach średniego dochodu winna być dostosowana do 5 typów sektorów wyznaczonych w zależności od odległości, jaka dzieli je od globalnej granicy technologicznej i dostosowywać do ich sytuacji różne kryteria pomocy. Są to sektory: doganiające, przodujące, tracące przewagę komparatywną, działające w krótkim cyklu innowacji oraz strategiczne, które mimo niezdolności do konkurencji są niezbędne do funkcjonowania całej gospodarki lub obrony narodowej.

Kraje rozwijające się korzystają z przewagi późnego przejęcia innowacji z krajów wysoko rozwiniętych i dlatego mogą się szybciej rozwijać od nich lecz większość z nich nie jest w stanie wyjść z pułapki średniego dochodu. NES ma zatem być „trzecią falą" przyspieszającą procesy innowacji technologicznych w przemyśle i całej gospodarce.

Chiny zamiast terapii szokowej polegającej na jednorazowym skokowym przejściu od gospodarki scentralizowanej do rynkowej, jak np. Polska, przyjęły podejście transformacji dwutorowej. Polegała ona na utrzymaniu protekcjonizmu państwowego w dawniej uprzywilejowanych branżach kapitałochłonnych przy jednoczesnym liberalizowaniu wejścia na rynek pozostałych branż, najczęściej pracochłonnych. Ten typ transformacji zakończył się sukcesem gospodarczym i społecznym Chin.

Powstaje pytanie, dlaczego rola państwa w generowaniu III fali przekształceń strukturalnych w gospodarce krajów doganiających jest tak ważna? Dlatego, 
że - zdaniem J.Y. Lina - poprawianie poziomu rozwoju infrastruktury i instytucji przekracza możliwości prywatnych firm. Tylko państwo ma możliwości realizacji tego zadania, które jest warunkiem dynamicznego rozwoju gospodarczego i społecznego. Jego zdaniem neoliberalizm „wylewał dziecko z kąpielą” odrzucając pomoc rządów w kreowaniu przekształceń strukturalnych.

Podzielam pogląd J.Y. Lina, że bez nowych innowacyjnych branż w gospodarce, i to głównie o charakterze narodowym, kraje znajdujące się w pułapce średniego dochodu nie mają szans na zdrowy rozwój gospodarczy. Pożądana polityka przemysłowa winna mieć na celu ułatwienie rozwoju branż posiadających ukryte przewagi komparatywne i umożliwianie im przejęcia funkcji narodowych przewag konkurencyjnych. Ukrytą przewagę komparatywną posiada branża, która posiada niższe koszty środków produkcji w stosunku do innych krajów świata. Firmy mogą stać się wydajne, a całe sektory konkurencyjne, gdy państwo pomoże im obniżyć koszty transakcji przez pomoc w zakresie koordynacji oraz poprawy twardej i miękkiej infrastruktury.

\section{Polska Strategia Odpowiedzialnego Rozwoju w świetle NOWEJ POKRYZYSOWEJ POLITYKI ROZWOJU i NoweJ EKonomil StRUKTURALNEJ}

Strategie rozwoju są najważniejszymi instrumentami realizacji proinnowacyjnych przekształceń strukturalnych w gospodarce i życiu społecznym. Mają one charakter długookresowy, dlatego że skala przemian zazwyczaj jest ogromna zarówno od strony techniczno-organizacyjnej i logistycznej, a zwłaszcza z uwagi na niezbędne do ich realizacji bardzo duże nakłady inwestycyjne. Żadna strategia rozwoju nie może mieć na starcie zabezpieczonych środków na jej realizację, lecz te środki musi stopniowo kreować oraz pozyskiwać na rynkach finansowych krajowych i zagranicznych. W warunkach gospodarki rynkowej państwo ma większe trudności jej realizacji niż w socjalizmie, gdyż większość środków produkcji jest własnością sektora prywatnego, krajowego i zagranicznego. Państwo będąc mniejszościowym właścicielem jest tylko głównym inspiratorem i koordynatorem strategii i poprzez zbiór instrumentów ekonomicznych, organizacyjno-prawnych, informacyjnych i instytucjonalnych stara się stworzyć warunki zachęcające podmioty prywatne do partycypowania $\mathrm{w}$ jej realizacji. Jest to zarazem warunek jej pełnej realizacji.

Jednakże tylko przy pomocy strategii rozwoju kraje i narody mogą sprostać wyzwaniom rozwojowym generowanym przez system globalny i dlatego są niezbędne, a nawet konieczne. Strategie rozwoju są zazwyczaj innowacjami skutkującymi przez dziesięciolecia pozytywnymi zmianami w gospodarce i życiu społecznym, a więc są innowacjami wielokrotnie wyższej rangi niż technologiczne. 
W polskiej historii do tego typu strategii znacząco zmieniających polską strukturę gospodarczą zaliczyć należy: Strategię rozwoju COP-u w II Rzeczypospolitej, Strategię uprzemysłowienia w PRL, po części Strategię dla Polski w III RP oraz obecną Strategię Odpowiedzialnego Rozwoju (SOR).

Przyjęta w Polsce SOR (Strategia..., 2017) zawiera w sobie wszystkie nowe wnioski i propozycje rozwojowe wynikające z krytyki neoliberalnego modelu rozwoju, który doprowadził do światowego kryzysu finansowego, ekonomicznego i społecznego.

Wiodącą zasadą Strategii Odpowiedzialnego Rozwoju jest zrównoważy rozwój całego kraju w czterech głównych wymiarach tj. gospodarczym, społecznym, środowiskowym i terytorialnym, z której efektów winni korzystać wszyscy obywatele Polski, co stanowi zarazem jej wymiar demokratyczny. Ta zintegrowana i zrównoważona strategia zakłada zwiększenie odpowiedzialności instytucji państwa za kształtowanie tych procesów.

Strategia Odpowiedzialnego Rozwoju z lutego 2017 roku (Strategia..., 2017) stanowi implementacje celów zrównoważonego rozwoju na poziomie krajowym i regionalnym. Zakłada ona wzmocnienie aktywnej roli państwa w rozwoju gospodarczym i społecznym, tworzy ramy prawne dla rozwoju, prowadzi strategiczną politykę inwestycyjną w wymiarze gospodarczym, społecznym i terytorialnym.

SOR jest strategicznym instrumentem zarządzania polityką rozwoju przez instytucje państwa. Jest ona nowym modelem rozwoju odpowiedzialnego, który budując siłę konkurencyjną polskiej gospodarki na bazie nowych czynników rozwoju zapewnia inkluzyjny udział wszystkich grup społecznych i regionów w jego efektach, dbając równocześnie o to, aby ten rozwój nie zmniejszał szans rozwojowych przyszłych pokoleń.

SOR jest nowy modelem rozwoju odpowiedzialnego, który wyraża się w:

- tym, że obecne bieżące decyzje rozwojowe zapewniają udział i korzyści wszystkim obywatelom i grupom społecznym, nie mogą dewastować zasobów naturalnych, środowiskowych i szans rozwojowych przyszłych pokoleń. Odpowiedzialny rozwój jest to zatem rozwój z myślą o przyszłych pokoleniach, a jednocześnie zrównoważony terytorialnie,

- antycypacyjnym zapobieganiu negatywnym procesom, a zarazem nakreśla najbardziej pożądane kierunki rozwoju wykorzystujące polskie potencjały rozwojowe,

- zwiększonej odpowiedzialności instytucji państwa za kształtowanie procesów gospodarczych, społecznych i terytorialnych oraz budowanie podstaw trwałego rozwoju na bazie własnych zasobów i nowych innowacyjnych działalności,

- urzeczywistnieniu zmiany podejścia do polityki rozwoju, która zaprojektowała działania wpływające na poszczególne strategiczne sfery życia społeczno-gospodarczego,

- zaspokajaniu potrzeb obecnego pokolenia bez umniejszania szans przyszłych pokoleń, 
- zapewnianiu właściwych relacji pomiędzy konkurencyjnością gospodarki, dbałością o środowisko naturalne oraz jakością życia społeczeństwa,

-wzroście gospodarczym opartym na solidnych fundamentach, jakimi są endogeniczne: przedsiębiorczość, pracowitość, zasoby, kapitał ludzki i umiejętności Polaków,

- wielowymiarowej solidarności społecznej, której celem jest troska o dobro wspólne - solidarność między pokoleniami, poszczególnymi regionami, miastami i obszarami wiejskimi, między pracodawcami i pracownikami,

- rozwoju nastawionym na wzmacnianie fundamentów polskiej gospodarki i kontynuowanie jej przekształceń strukturalnych w kierunku zwiększenia roli innowacyjności w procesach gospodarczych,

- odpowiedzialna gospodarka winna tworzyć bardziej stabilne, i lepsze miejsca pracy czyli bardziej wydajne i lepiej opłacane, niezbędne do dalszego rozwoju oraz bezpieczeństwa dochodowego Polaków i wzrostu ich zamożności,

- fundamentem odpowiedzialnej i stabilnej gospodarki są rosnące w siłę innowacyjne przedsiębiorstwa różnej wielkości i gospodarstwa rolne oraz ich współpraca,

- odpowiedzialny rozwój oznacza równowagę między środkami krajowymi i zagranicznymi wspierającymi rozwój tak aby zwiększyć w przyszłości możliwości czerpania korzyści ze wzrostu gospodarczego,

- odpowiedzialny rozwój oznacza politykę budowania krajowego i polonijnego kapitału, w szczególności poprzez zwiększanie oszczędności i jego inwestowanie,

- odpowiedzialny rozwój oznacza pomnażanie polskiego kapitału ludzkiego, który kluczem do sukcesu i najbardziej efektywną inwestycją rozwojową przynoszącą efekty przez dziesięciolecia, np. COP,

- odpowiedzialny rozwój oznacza działania na rzecz rozwoju demograficznego i zastępowalności pokoleń, które są warunkiem trwałego rozwoju,

- odpowiedzialność to solidarność międzypokoleniowa, sprawiedliwy system emerytalny polegająca na znajdowaniu takich rozwiązań, które pozwalają na aktywne włączenie w procesy rozwojowe wszystkich grup społecznych, dając im jednocześnie możliwość czerpania korzyści ze wzrostu gospodarczego,

- rozwój odpowiedzialny to rozwój włączający, inkluzyjny włączający wszystkie grupy społeczne, a nie wykluczający, czyli ekskluzyjny,

- rozwój odpowiedzialny to model postPKB-owski, w którym chodzi nie tylko o wartość wytworzonego PKB, ale głównie o jego jakość, wielkość wartości dodanej, która zostaje w kraju i dlatego ma duże znaczenie dla standardu życia obywateli.

SOR jest aktualnie nowym modelem zrównoważonego rozwoju, który suwerennie określa strategiczną wizję rozwoju Polski, zasady oraz cele i priorytety rozwoju w czterech wymiarach: gospodarczym, społecznym, przestrzennym i ekologicznym do 2020 roku wraz z perspektywą do 2030 roku. Zmienia ona jednocześnie wszystkie dotychczasowe strategiczne ustalenia rozwoju Polski. 
Głównym celem SOR jest stworzenie warunków dla zwiększenia dochodów i zamożności mieszkańców Polski, a tym samym zwiększenie spójności w wymiarze społecznym, gospodarczym, terytorialnym i środowiskowym.

Ten cel główny ma zostać zrealizowany przez trzy strategiczne cele szczegółowe: - I szczegółowy cel strategiczny zakłada osiągnięcie trwałego rozwoju gospodarczego na bazie innowacyjnej gospodarki opartej na wiedzy i dobrej organizacji, w pięciu obszarach działań: reindustrializacji, rozwoju innowacyjnych firm, małych i średnich przedsiębiorstw, kapitału dla rozwoju oraz ekspansji zagranicznej.

- II strategiczny cel szczegółowy dotyczy rozwoju społecznie wrażliwego i terytorialnie zrównoważonego, w dwóch obszarach: spójność społeczna oraz rozwój zrównoważony terytorialnie.

- III strategiczny cel szczegółowy obejmuje: skuteczne państwo i instytucje służące wzrostowi oraz włączeniu społecznemu i gospodarczemu. Działania koncentrują się w pięciu obszarach problemowych: prawo w służbie obywatelom i gospodarce, instytucje prorozwojowe i strategiczne zarządzanie rozwojem, państwo, finanse publiczne, efektywność wykorzystania środków UE.

Stosownie do tych celów SOR podjęte zostały działania w polityce gospodarczej, demograficznej, dochodowej i antypolaryzacyjnej, regionalnej oraz ekologicznej. Kierunki tych działań są zgodne z zaleceniami T. Pikettego oraz J.Y. Lina, ale także uwzględniają specyficzne polskie uwarunkowania i wyzwania.

Do najważniejszych działań strategicznych SOR zaliczyć należy:

- podjęcie programu rozwoju demograficznego, rozwoju społecznie wrażliwego,

- stabilizację sektora finansów publicznych, a zwłaszcza uszczelnienie dochodów budżetu państwa

- przyjęcie koncepcji reindustrializacji polskiej gospodarki i zwiększenie w niej udziału polskiej własności oraz firm sektora innowacyjnego (Przemysł 4.0),

- renacjonalizację znacznej części sektora bankowego w Polsce,

- wspieranie innowacyjności polskich firm i ich ekspansji zagranicznej oraz przedsiębiorczości,

- program tworzenia polskiego kapitału rozwojowego na bazie głównych publicznych firm polskich i kapitału polskiego społeczeństwa, stworzenie Polskiego Funduszu Rozwoju,

- przyjęcie zrównoważonej koncepcji rozwoju regionalnego i lokalnego oraz rozwoju obszarów wiejskich.

\section{WNIOSKI KOŃCOWE}

Główną zaletą polskiej Strategii Odpowiedzialnego Rozwoju jest to, że implementuje ona wszystkie pokryzysowe doświadczenia i nowe teorie rozwoju, 
które stwarzają krajom rozwijającym się szanse na przełamanie bariery średniego rozwoju. Szanse te wynikają również z zintegrowanego i zrównoważonego charakteru nowej strategii rozwoju, która zakłada synergiczne efekty rozwojowe wynikające z integracji rozwoju gospodarczego, społecznego, ekologicznego i przestrzennego.

Ten zintegrowany i harmonijny polski model rozwoju i strategia jego realizacji są zbieżne z najnowszymi tendencjami teoretycznymi i praktycznymi w gospodarce światowej. Pierwsze działania wdrożeniowe tej polskiej SOR okazały się nadzwyczaj skuteczne, zarówno od strony ekonomiczno-finansowej jak również społecznej, co dobrze rokuje na przyszłość.

Realizacja dalszych projektów rozwojowych zawartych w SOR wymaga współpracy zarówno polskiego sektora przedsiębiorstw, jak również korporacji zachodnich oraz krajowych i międzynarodowych instytucji finansowych.

Niezbędne jest również poparcie polskiego społeczeństwa dla zapewnienia odpowiedniego czasu do jej pełnego zrealizowania. Wydaje się, że ten czas polska SOR otrzyma, gdyż realizuje programy społeczne cieszące się akceptacją większości obywateli, czyli ma poparcie demokratyczne.

\section{BIBLIOGRAFIA}

Dlaczego w bogatych krajach Europy Zachodniej zarabia się 4 razy więcej niż u nas. Jaki ja mam na to wplyw? Nowy Sącz: Fundacja Pomyśl o przyszłości.

Encyklika „Caritas in veritate” Ojca świętego Benedykta XVI, O integralnym rozwoju ludzkim w miłości i prawdzie. (2009). Libreria Editrice Vaticana.

Encyklika Jana Pawła II „,Sollicitudo rei socialis”. (1987). Libreria Editrice Vaticana.

Karpiński, A. (2002). Co dalej z przemystem w Polsce? Zarys strategii przemystowej na lata 2005-2015. W: Komitet Prognoz „POLSKA 2000 Plus” przy Prezydium PAN, Biuletyn nr 1/2003, Warszawa: DOM WYDAWNICZY ELIPSA.

Kołodko, G.W. (2010a). Neoliberalizm i systemowy kryzys globalnej gospodarki. W: G.W. Kołodko (red.), Globalizacja, kryzys i co dalej? Warszawa: Wydawnictwo Poltext.

Kołodko, G.W. (2010b). Świat na wyciągnięcie myśli. Warszawa: Prószyński i S-ka.

Kowalik, T. (2010a). Kryzys systemu w perspektywie alterglobalizmu. W: G.W. Kołodko (red.), Globalizacja, kryzys i co dalej? Warszawa: Wydawnictwo Poltext.

Kowalik, T. (2010b). Szokowa operacja i opcje alternatywne. W: S. Owsiak (red.), 20 lat przemian ustroju gospodarczego Polski. Dokonania i wyzwania. Kraków: Wydawnictwo Uniwersytetu Ekonomicznego w Krakowie.

Lin, J.Y. (2017). Nowa Ekonomia Strukturalna dla gospodarek doganiających. W: J.Y. Lin, A.Z. Nowak (red.), Nowa Ekonomia Strukturalna wobec krajów mniej zaawansowanych. Warszawa: Wydawnictwo Naukowe Wydziału Zarządzania UW.

Mączyńska, E., Pysz, P. (2014). Liberalizm, neoliberalizm i ordoliberalizm. Ekonomista, 3. Piketty, T. (2015). Kapitat w XXI wieku. Warszawa: Krytyka polityczna.

Plan na rzecz Odpowiedzialnego Rozwoju. (2016). Ministerstwo Rozwoju, Warszawa. 
Prusek, A. (2005). Prywatyzacja polskiej gospodarki-cele, programy i ocena jej rezultatów. Kraków: Akademia Ekonomiczna w Krakowie.

Prusek, A. (2009). Dywergencja płacowo-dochodowa w Polsce i scenariusze jej zmniejszania w warunkach integracji europejskiej. Zeszyty Naukowe Uniwersytetu Ekonomicznego w Krakowie, 863.

Prusek, A. (2011). Wyzwania modelowe gospodarki światowej i polskiej polityki ekonomicznej wynikające ze światowego kryzysu finansowego i ekonomicznego. W: A. Prusek (red.), Wyzwania polityki ekonomicznej w warunkach światowego kryzysu finansowego i gospodarczego. Kraków: Wydawnictwo Uniwersytetu Ekonomicznego w Krakowie.

Prusek, A. (2012a). Główne wyzwania i bariery rozwoju społeczno-ekonomicznego Polski do 2020 roku. W: A. Prusek (red.), Wyzwania i bariery rozwoju społeczno-ekonomicznego Polski do 2020 roku (s. 51-63). Kraków: Uniwersytet Ekonomiczny w Krakowie i WSGiZ w Krakowie.

Prusek, A. (2012b). Społeczno-demograficzne i dochodowe mega wyzwanie rozwojowe Polski - w warunkach globalnego kryzysu neoliberalizmu. W: E. Pancer-Cybulska (red.), Polska i europejska polityka gospodarcza wobec wyzwań XXI wieku. Wrocław: Wydawnictwo Uniwersytetu Ekonomicznego we Wrocławiu.

Prusek, A. (2015). Nowy model polityki ekonomiczno-społecznej jako wyzwanie dla Polski w warunkach neoliberalnego kryzysu. W: E. Mączyńska (red.), Modele ustroju społeczno-gospodarczego. Kontrowersje i dylematy. IX Kongres Ekonomistów Polskich. Warszawa: PTE.

Prusek, A. (2017). Neoliberalna polaryzacja dochodowo-majątkowa i jej konsekwencje dla rozwoju ekonomicznego i społecznego. Prace Naukowe Uniwersytetu Ekonomicznego we Wroctawiu, 489. DOI: 10.15611/pn.2017.489.29.

Sachs, J.D. (2007). Wspólne wyzwania, wspólne dobro. Wykład doktora h.c. Uniwersytetu Ekonomicznego w Krakowie wygłoszony 2 października 2007 r.

Strategia na rzecz Odpowiedzialnego Rozwoju do roku 2020 (z perspektywa do 2030). Załacznik do uchwały nr 8 Rady Ministrów z dnia 14 lutego 2017 roku. Warszawa.

Tomczak, D.A. (2017). Równość społeczna jako czynnik rozwoju gospodarczego - doświadczenia skandynawskie. Biuletyn PTE 1 (76).

Żyżyński, J. (2010). Neoliberalizm - ślepa uliczka globalizacji. W: G.W. Kołodko (red.), Globalizacja, kryzys i co dalej? Warszawa: Wydawnictwo Poltext.

\section{Streszczenie}

Celem artykułu jest pokazanie relacji i współzależności między nowymi pokryzysowymi teoriami i politykami rozwoju zrównoważonego a wdrażaną obecnie w Polsce Strategią Odpowiedzialnego Rozwoju. Autor wykazuje, że SOR integruje nowe teorie rozwoju zrównoważonego i inkluzyjnego oparte na badaniach T. Pikettego dotyczących znaczenia zmniejszania nierówności dochodowych dla rozwoju oraz Nowej Ekonomii Strukturalnej Justina Yifu Lina zakładającej zwiększoną odpowiedzialność państwa za kształtowanie procesów rozwojowych.

Słowa kluczowe: nowa ekonomia strukturalna, rozwój zrównoważony, strategia rozwoju. 


\section{The new post-crisis policy of sustainable development and the Polish Strategy of Responsible Development}

\section{Summary}

The aim of the article is to show the relations and interdependencies between the new post-crisis theories and policies for sustainable development and the Responsible Development Strategy currently being implemented in Poland. The author shows that SOR integrates new theories of sustainable and inclusive development, based on T. Piketty's research on the importance of reducing income inequalities for development, and New Structural Economics described by Justin Yifu Lin and assuming the increased state responsibility for shaping development processes.

Keywords: New Structural Economics, sustainable development, strategy of development.

JEL: H00, O10, O20, O21, O25. 